удК 342.6

DOI https://doi.org/10.32837/apdp.v0i89.3186

В. О. Кожевніков

\title{
ПОРІВНЯЛЬНО-ПРАВОВИЙ АНАЛІЗ СТАТУСУ АНТИМОНОПОЛЬНИХ ОРГАНІВ УКРАЇНИ ТА ІНОЗЕМНИХ ДЕРЖАВ У СИСТЕМІ ОРГАНІВ ПУБЛІЧНОЇ АДМІНІСТРАЦІї
}

Постановка проблеми. Інтеграція України в Європейський Союз потребує, зокрема, ефективного здійснення державної політики у сфері захисту та розвитку економічної конкуренції та недопущення зловживань монопольним (домінуючим) становищем суб'єктів господарювання. На даний час йдуть жваві дискусії про необхідність проведення антимонопольно-конкурентної реформи в України, що передбачає, зокрема, зміну правового статусу Антимонопольного комітету України (основні бачення реформи викладені в законопроектах № 2730, 2730-1, 2730-2, 3132 3779, 3779-1).

Аналіз останніх досліджень і публікацій. Окремим питання адміністративно-правового статусу антимонопольних органів присвяченні праці таких вчених, як С.В. Шкляр, Т.I. Швидка, О.О. Плєтньова, О.В, Пономарьов та інші. Разом із цим питання вдосконалення адміністративно-правового статусу Антимонопольного комітету України в сучасних умовах залишається недостатньо розробленим.

Метою дослідження є аналіз місця антимонопольних органів України та зарубіжних країн у системі органів публічної адміністрації, розгляд ступеню впливу вищих органів виконавчої влади держави (Уряду, Президента) на конкурентні відомства, розмежування повноважень між Урядом та антимонопольним органом.

Виклад основного матеріалу. Як свідчить міжнародна практика, у світі, в тому числі в Свропі, на сьогодні існує дві основні моделі, що визначають правове становище антимонопольного органу і його місце серед органів публічної адміністрації.

Перша модель передбачає наділення антимонопольного органу статусом центральногоорганувиконавчоївлади. Хочайконкурентнимзаконодавствомнадаються додаткові гарантії та повноваження під час забезпечення захисту економічної конкуренції, в цілому такі антимонопольні органи входять до складу Уряду, підзвітні йому. Так, наприклад, Федеральна антимонопольна служба Російської Федерації є звичайним федеральним органом виконавчої влади та підзвітна Уряду Росії [1].

Разом із тим російські правники відзначають про необхідність посилення незалежності антимонопольної служби за зразком Федеральної торгової комісії США. Національна асоціація інститутів закупівель Росії пішла ще далі, запропонувавши прирівняти статус Федеральної антимонопольної служби Росії до статусу Федеральної резервної системи США - американського центрального банку [2].

Схожі пропозиції також мали місце і в Україні. Так, екс-голова Антимонопольного комітету України (далі - Комітет) висловлював думку про те, що статус службовців Антимонопольного комітету повинен бути аналогічним до службовців Національного банку України. Поширеною у свій час була теза про те, що Комітет 
є своєрідною «економічною прокуратурою», що саме по собі може сприйматися як аргумент на користь здобуття значної незалежності антимонопольного органу [3].

Як зауважує О. Дякулич, жоден інший державний орган не може накладати такі великі штрафи (розмір штрафу за порушення законодавства про захист економічної конкуренції розраховується як процент з обороту суб'єкта господарювання). Так, наприклад, накладений АМКУ штраф на Газпром склав 85,966 млрд гривень [4].

При цьому повноваження суду обмежені перевіркою законності накладання штрафів у разі оскарження рішення Комітету про накладання штрафу. У судовій практиці суди неодноразово зазначають, що розмір накладеного штрафу є виключною компетенцією Комітету, і суд його змінювати не вправі, якщо він призначений у межах, встановлених законом. Значна дискреція антимонопольних органів України, повноваження накладати штрафи у великих розмірах, що не потребує судового затвердження, дають підстави вважати Антимонопольний комітет України квазісудовим органом [5].

У деяких країнах відсутній окремий антимонопольний орган, а його функції виконує відповідне міністерство (як правило, що відповідає за економічний розвиток). Наприклад, Міністерство антимонопольного регулювання і торгівлі Республіки Білорусь, Міністерство національної економіки Республіки Казахстан, Міністерство комерції Китайської Народної Республіки, Управління з питань конкуренції Міністерства економіки Албанії).

У цілому такий підхід має як свої недоліки, так і переваги. Функціонування незалежного від Президента та / або Уряду антимонопольного органу дозволяє ефективно уникати конфлікту інтересів, особливо це актуально під час розгляду правопорушень у вигляді антиконкурентних дій органів влади. Проведення таких розслідувань, що нерідко пов'язані і з корупційними схемами, можуть завершитися звільненням керівника антимонопольного відомства, блокуванням фінансування органу, його реорганізації тощо.

З іншого боку, саме Уряд (як, наприклад, Кабінет Міністрів України) наділений Конституцією повноваженнями щодо здійснення економічної політики і відповідальний за цей напрямок державної політики. Якщо, наприклад, статус Національного банку України як незалежного регулятора прямо прописаний в Основному законі нашої держави, то щодо Антимонопольного комітету України таких застережень в Конституції України немає. Інакше кажучи, можна стверджувати, що незалежний антимонопольний орган обмежує можливості політичного впливу (в тому числі законного впливу з боку Уряду) на антимонопольну політику.

У державах, де антимонопольні органи прирівняні до центральних органів виконавчої влади чи діють у складі міністерств, керівники таких органів є політичними діячами, які безпосередньо підзвітні Уряду. Закон України «Про Антимонопольний комітет України» закріплює незалежність Комітету від Кабінету Міністрів України в питаннях підзвітності та відповідальності.

При цьому це не означає що Уряд не може самостійно реалізовувати конкурентну політику без погодження з Антимонопольним комітетом України. Напевно, найбільш вагомими питаннями, де можуть перехрещуватися інтереси національ- 
ної конкурентної політики уряду та антимонопольного органу, є надання дозволів на концентрацію та державна допомога суб'єктам господарювання. У рамках загострення міжнародної конкуренції між Свропейським Союзом та Китаєм у 2019 році промислові гіганти Свропи у сфері виробництва потягів Alstom i Siemens здійснили спробу злиття, яке було ветоване конкурентним відомством Європейського Союзу Європейською комісією. Хоча й Європейська комісія зазначила, що «китайська загроза» на товарних ринках Європейського Союзу з виробництва високошвидкісних потягів в реальності відсутня і саме через це концентрація була заборонена, таке рішення дістало вкрай негативну реакцію вищого політичного керівництва Франції та Німеччини. На цьому фоні з боку ФРН та Франції все частіше лунають ідеї щодо необхідності змін конкурентного законодавства ЄС [6].

Слід зауважити, що в деяких країнах світу політична влада в тому числі Уряд все ж таки має обмежене право контролю за незалежними антимонопольними органами. Так, наприклад, незважаючи на незалежний статус німецького конкурентного відомства, його рішення в області злиття може спеціальним указом скасувати міністр економіки. Цим правом у 2005 році скористався міністр Вернер Мюллер. Він наклав вето на заборону відомства про злиття енергетичних концернів Е.ON i Ruhrgas. Сьогодні компанія E.ON Ruhrgas контролює 60 відсотків імпорту газу в Німеччині [7].

Аналогічне положення міститься і в Законі України «Про захист економічної конкуренції» (частина 2 статі 25), який був підготовлений під значним впливом німецького антимонопольного законодавства. Варто зауважити, що на практиці дана норма в Україні не застосовувалася. Незважаючи на функціонування незалежної Федеральної торгової комісії США, Міністерство юстиції США (що виконує функції американської прокуратури), яке очолює міністр, що призначається Президентом Сполучених Штатів, наділено компетенцією звертатися до суду із цивільними позовами за відшкодування збитків, завданих економічній конкуренції.

Так, наприклад, Мін'юст США звернувся зі цивільним позовом проти компанiї Google. Як зазначив заступник міністра юстиції Сполучених Штатів Америки Джеффрі Розен, корпорація, завдає серйозної шкоди конкуренції на онлайн - майданчиках [8].

Щодо державної допомоги суб’єктам господарювання, то Кабінет Міністрів України обмежений повноваженнями приймати критерії оцінки допустимості окремих категорій державної допомоги. Передбачені Конституцією України повноваження Кабінету Міністрів у сфері економічної політики не є безмежними, а повинні здійснюватися з урахуванням інших конституційних норм, в тому числі статті 42 Конституції України, відповідно до якої не допускається неправомірне обмеження конкуренції.

Оновлена стратегія промислової політики Європейського Союзу розглядає промисловість як основу економічного процвітання і ставить завдання з підтримки і зміцнення промислового лідерства Європи в епоху глобалізації, швидких технологічних змін і викликів стабільному розвитку [9].

Тому в провідних країнах промисловість цілеспрямовано розвивають у тому числі шляхом застосування інструментів державної допомоги. 
У сучасних умовах світової економічної кризи, викликаною короновірусом та швидкими темпами науково-технічного прогресу, роль держави в економіці знову посилюється. Ідеї сильної держави стають все більш популярними в тому числі у країнах ліберальних демократій. Так, наприклад, Італійський уряд у 2020 році прийняв рішення про націоналізацію приватних лікарень та збанкрутілих авіакомпаній. Як зауважує економіст В. Катасонов, під час здійснення індустріалізації промисловості шляхом їі насичення робототехнікою провідна роль буде відведена саме держаному фінансуванню [10].

У цілому збільшення присутності держави в економіці, як правило, чинить негативно вплив на конкуренцію, проте такі дії водночас мають позитивні наслідки, зокрема збереження / збільшення кількості робочих місць, посилення конкурентоздатності вітчизняної продукції, забезпечення інших національних інтересів (у тому числі у сфері охорони здоров’я у випадку націоналізації лікарень), збільшення доходів держави, виконання соціальних зобов'язань держави державними підприємствами (йдеться, зокрема, про доставку «Укрпоштою» пенсій в сільську місцевість, що є збитковим).

Другий варіант інституційної побудови антимонопольного органу передбачає функціонування незалежного колегіального органу (за прикладом Федеральної торгової комісії США).

Особливості організаційної побудови та адміністративно-правових засад діяльності Антимонопольного комітету України (колегіальність органу, призначення його членів на 7 років, участь Президента та парламенту в призначенні державних уповноважених Комітету, незалежність у відносинах з іншими державними органами) свідчать про існування схожих ознак у статусі американського та українського антимонопольних органів. Діяльність американського антимонопольного відомства регламентована Федеральним законом США «Про Федеральну торгову комісію» 1914 року [10].

Федеральна торгова комісія США не входить до складу Кабінету Президента США (американський аналог Уряду), а тому зі зміною Президента США як голови виконавчої влади члени Федеральної торгової комісії США продовжують свою діяльність. Строк іх повноважень складає 7 років. Разом із цим Президент США наділений повноваженнями звільняти членів ФТК за неефективність, недбале відношення до роботи, вчинення посадових злочинів.

Закон України «Про Антимонопольний комітет України» містить аналогічні норми, якими встановлюються гарантії від безпідставного звільнення членів Комітету (стаття 17). Разом із цим аналіз даної норми свідчить про її недосконалість та наявність логічних помилок. У статті 17 Закону України «Про Антимонопольний комітет України» вказано, що Перший заступник, заступник Голови Антимонопольного комітету України, державний уповноважений Антимонопольного комітету України, крім загальних підстав, передбачених законодавством про працю та про державну службу, може бути звільнений із посади:

1) за станом здоров’я, який перешкоджає продовженню роботи;

2) за власним бажанням; 
3) у разі грубого порушення службових обов'язків або набрання законної сили обвинувальним вироком суду стосовно такої особи за вчинення кримінального правопорушення.

По-перше, державні уповноваженні Антимонопольного комітету України не є державними службовцями відповідно до чинного законодавства. Члени Комітету були державними службовцями відповідно до статті 2 Закону України «Про державну службу» від 17. 11. 2011 року. Із прийняттям чинного Закону України «Про державну службу» 2015 року положення статті 17 Закону України «Про Антимонопольний комітет України» не були приведені у відповідність до нього.

По-друге, звільнення за станом здоров'я, що перешкоджає подальшій роботі і є загальними підставами звільнення передбаченими законодавством про працю (стаття 39 Кодексу законів України про працю). Виглядає нелогічним повторне згадування у правовій нормі цієї підстави звільнення. Право на звільнення за власним бажанням регламентується чинним Законом України "Про державну службу» (частина перша статті 86), тому ця підстава звільнення також дублюється.

Особливий статус Комітету зумовлюється в том числі особливою процедурою звільнення його членів (частина 2 статті 1 Закону України «Про Антимонопольний комітет України»). Чинна редакція даної статті жодних гарантій в цьому питанні не встановлює, адже підстави звільнення членів Комітетів тотожні (навіть їх перелік є більшим за рахунок підстав вказаних в трудовому законодавстві) підставам звільнення державних службовців апаратів державних органів.

Виходячи з вищевикладеного, вбачається за доцільне слова «крім загальних підстав, передбачених законодавством про працю та про державну службу» виключити.

Зрозуміло, що грубе порушення службових обов'язків (як і неефективність та недбале відношення до роботи за законодавством США) є оціночним поняттям. Разом із цим такі підстави можуть бути предметом судового розгляду.

Відповідно до директиви Свропейського Парламенту 2009/140 / CE керівник регулюючого органу або члени такого колегіального органу можуть бути звільнені, тільки в разі якщо вони не відповідають вимогам, необхідним для виконання своїх обов'язків, за умови, що ці вимоги будуть сформульовані в законодавстві. Рішення про звільнення має бути опубліковано. Звільнена посадова особа має отримати письмове пояснення про причини звільнення і має право вимагати опублікування цього рішення і мотивів звільнення [11].

Указами Президента України було звільнено державних уповноважених Комітету. При цьому Президент України в Указах Президента України від 5 липня 2019 року № 486/2019 та від 08 липня 2019 року № 496/2019 посилається на частину 1 статті 10, частину 1 статті 11, де закріплено право Президента звільняти членів Комітету, хоча підстави для звільнення державних уповноважених встановлені у статті 17 Закону України «Про Антимонопольний комітет України». В Указі Президента України «Про звільнення Н. Сидоренко з посади заступника Голови Антимонопольного комітету України - державного уповноваженого» від 29 липня 2020 року № 298/2020 посилання на статтю закону України «Про Антимонопольний комітет України» взагалі відсутнє. 
Указ Президента України від 5 липня 2019 року № 486/2019 було оскаржено в судовому порядку. Суд визнав Указ правомірним, адже державна уповноважена була раніше притягнута до адміністративної відповідальності за порушення, пов'язане з корупцією, і Президент України здійснив звільнення на основі «загальних підстав звільнення державних службовців» [12].

Вчинення таких правопорушень є підставою для звільнення з державної служби. При цьому, як свідчить аналіз Єдиного реєстру осіб, які вчинили корупційні або пов'язані з корупційними правопорушення, інші звільненні члени Комітету до аналогічної відповідальності не притягувалися.

Таким чином, на наш погляд, існування бланкетних норм, що встановлюють підстави звільнення членів Комітету, є невдалим.

Слушним у цьому контексті можуть бути підстави припинення повноважень членів НКРЕКП, де надається вичерпний перелік підстав для дострокового припинення повноважень членів Комісії (частина 7 статті 8).

У законі України «Про Національну комісію, що здійснює державне регулювання у сферах енергетики та комунальних послуг» прямо закріплено, що не може бути підставою для звільнення члена, відставки Кабінету Міністрів України чи формування його нового складу.

Висновки. Аналіз адміністративно-правового статусу антимонопольних органів держав світу дає можливість виділити дві основні моделі інституційної побудови антимонопольного органу.

У першій моделі (до якої належать Україна, США) антимонопольний орган має значну інституційну незалежність від Уряду, напряму не підзвітний та не відповідальний перед Урядом, а його вищі посадові особи продовжують діяльність у випадку відставки Уряду, парламентських або президентських виборів протягом строку визначеного в законі (7 років - для Антимонопольного комітету України). У другій моделі (Російська Федерація, Республіка Білорусь, Республіка Казахстан, Китайська Народна Республіка, Албанія) антимонопольний орган за організаційною оструктурю є центральним органом виконавчої влади (міністерством, службою), який безпосередньо підзвітний вищому органу виконавчої влади.

Більш ефективним вважаємо другий варіант інституційної побудови антимонопольного органу, оскільки саме незалежність від інших державних органів забезпечує найбільшу ефективність здійснення захисту економічної конкуренції, в тому числі від антиконкурентних дій органів влади. Забезпечення незалежності Антимонопольного комітету України здійснюється, зокрема, через особливу процедуру звільнення його членів. У зв'язку з недосконалістю правових норм на практиці виникли проблеми правозастосування.

Виходячи з вищенаведеного, пропонуємо внести зміни до Закону України «Про Антимонопольний комітет України», виклавши статтю в такій редакції:

«Стаття 18. Підстави звільнення з посад Голови, Першого заступника, заступників Голови Антилонопольного комітету України, державних уповноважених Антимонопольного колітету України

Не може бути підставою для звільнення Голови, Першого заступника, заступників Голови Антимонопольного комітету України, державних уповноважених Анти- 
монопольного комітету України формування нового складу Кабінету Міністрів України, обрання нового складу Верховної Ради України або Президента України.

Вичерпний перелік підстав для звільнення Голови, Першого заступника, заступників Голови Антимонопольного комітету України, державних уповноважених Антимонопольного комітету України визначається цим законом. Акт про звільнення повинен містити посилання на підстави звільнення та обгрунтовувати їх. Рішення про звільнення може бути оскаржене в судовому порядку.

Повноваження Голови, Першого заступника, заступників Голови Антимонопольного комітету України, державних уповноважених Антимонопольного комітету України припиняються достроково у випадку:

1) грубого порушення встановлених законодавством службових обов'язків;

2) визнання його судом недієздатним або обмежено дієздатним, визнання його безвісно відсутнім чи оголошення його померлим;

3) набрання законної сили обвинувальним вироком суду стосовно нього;

4) набрання законної сили рішенням суду про притягнення до відповідальності за корупційне правопорушення або правопорушення, пов'язане з корупцією;

5) припинення його громадянства України або виїзду на постійне проживання за межі України;

6) подання заяви про звільнення з посади за власним бажанням, в разі неможливості виконувати свої повноваження за станом здоров'я або в разі виходу на пенсію;

7) подання заяви про відставку в разі принципової незгоди з рішенням (рішеннями) Антимонопольного комітету України;

8) смерті».

\section{Jimepamypa}

1. Гуревич В.А. Федеральная антимонопольная служба: правовой статус требует уточнения. ВЭПС. 2009. № 2. URL : https://cyberleninka.ru/article/n/federalnaya-antimonopolnaya-sluzhba-pravovoystatus-trebuet-utochneniya (дата звернення: 03.02.2020).

2. О статусе и полномочиях антимонопольного органа в России и за рубежом. Национальная ассоциация институтов закупок. 2012. URL : http://naiz.org/arhive/analitics/rubrics/68/501/ (дата звернення: 03.02.2020).

3. Дякулич О. Демонополізація і дерегуляція «своїми руками»: покрокова інструкція для бізнесу. Рекомендації від АО «Арцінгер». Ліга: Закон. 2020. URL : https://biz.ligazakon.net/analitycs/196112 demonopolzatsya--deregulyatsya-svomi-rukami-pokrokova-nstruktsya-dlya-bznesu (дата звернення: 03.02.2020).

4. Газпром обжаловал штраф АМКУ на 172 миллиарда гривен. Європейська правда. 2017. URL : https://www.epravda.com.ua/rus/news/2017/03/20/622863/.

5. Гоголь М. Як і кого карає АМКУ за змову. Ліга. Блоги. 2018. URL : https://blog.liga.net/user/ mgogol/article/29704 (дата звернення: 03.02.2020).

6. Германскому антимонопольному ведомству - 50 лет. Deutsche Welle. 2008. URL : https://www.dw.com/ru/германскому-антимонопольному-ведмоству-50-лет/а-3073362 (дата звернення: 03.02.2020).

7. Top Investigator in Google Case Says There 'Was Not a Rush' to Sue. The New York Times. 2020. URL : https://www.nytimes.com/2020/10/22/technology/doj-google-jeffrey-rosen.html (дата звернення: 03.02.2020).

8. Новицький В.С. Нова індустріалізація - реальний шанс для України. Антикризова рада громадських організацій України. 2018. URL : https://uspp.ua/assets/doc/maket_nov_2019.pdf.

9. Federal Trade Commission Act. Office of the Law Revesion Counsil. United States Code. URL:https://uscode.house.gov/view.xhtml?req=granuleid\% 3AUSC-prelim-title15-chapter2-subchapter1\& edition=prelim (дата звернення: 03.02.2020). 
10. Directive 2009/140/EC of the European Parliament and of the Council of 25 November 2009. Official Journal of the European Union. 2009. URL : https://eur-lex.europa.eu/legal-content/EN/TXT/ HTML/?uri=CELEX:32009L0140\&from=EN (дата звернення: 03.02.2020).

11. Рішення Верховного суду від 09 липня 2020 року у справі №9901/372/19. URL : https://reyestr.court.gov.ua/Review/90366992 (дата звернення: 03.02.2020).

12. Катасонов В. Короновирус. От вируса к диктатуре. Финансовые хроники профессора Катасонова. Книжный мир. 2020. URL : http://loveread.ec/view_global.php?id=89281 (дата звернення: 03.02.2020).

\section{Анотація}

Кожевніков В. О. Порівняльно-правовий аналіз статусу антимонопольних органів України та іноземних держав у системі органів публічної адміністрації. - Стаття.

Стаття присвячена особливостям адміністративно-правового статусу антимонопольного органу в системі органів державної влади за законодавством України та зарубіжних країн. Запропоновано типологізацію антимонопольних органів залежно від впливу вищих органів виконавчої влади (Уряду або Президента залежно від різновиду республіканської форми правління). Аналіз адміністративно-правового статусу антимонопольних органів іноземних держав дає можливість виділити два основних види інституційної побудови антимонопольного органу. У першому випадку конкурентне відомство є центральним органом виконавчої влади, який є підзвітним та підконтрольним вищому органу виконавчої влади (Уряду або Президенту). Здебільшого, але не завжди, це одноосібний орган (Міністерство, служба), керівник якого призначається за загальною процедурою призначення міністрів, керівників центральних органів виконавчої влади. У другому випадку, як це має місце і в України, антимонопольний орган не входить до складу Уряду (або Кабінету Президента), прямо не підзвітний вищому органу виконавчої влади. Акцентовано увагу на процедурах призначення та звільнення керівництва антимонопольного органу, взаємовідносинах конкурентного відомства з вищими органами виконавчої влади держави. Проаналізовано правозастосовчу практику діяльності конкурентного відомства Європейського Союзу - Європейської Комісії під час надання дозволів на концентрацію у стратегічних сферах економіки Європейського Союзу, де посилюється міжнародна конкуренція з боку Китайської Народної Республіки. Розглянуто вітчизняну судову практику оскарження указу Президента України про звільнення члену Антимонопольного комітету України. Окреслено питання ролі антимонопольних органів та Уряду у сфері контролю за допустимістю державної допомоги суб'єктам господарювання.

З урахуванням вітчизняної судової практики та федерального законодавства США (зокрема, федерального закону США «Про Федеральну торгову комісію») надано пропозиції щодо вдосконалення порядку звільнення Першого заступника, заступників Голови Антимонопольного комітету України, державних уповноважених Антимонопольного комітету України.

Ключові слова: антимонопольні органи, статус антимонопольних органів зарубіжних країн, Антимонопольний комітет України, процедура звільнення членів Антимонопольного комітету України, антимонопольні органи США.

\section{Summary}

Kozhevnikov $\mathrm{V}$. O. Comparative analysis of the status of the antimonopoly bodies of Ukraine and foreign countries in the system of public administration bodies. - Article.

The article is devoted to the peculiarities of the administrative and legal status of the antimonopoly body in the system of public authorities under the legislation of Ukraine and foreign countries. The typology of antimonopoly bodies depending on the influence of higher executive bodies (Government or President depending on the type of republican form of government) is proposed. Analysis of the administrative and legal status of antitrust authorities of foreign countries makes it possible to identify two main types of institutional development of the antitrust authority. In the first case, the competition authority is a central executive body that is accountable to and under the control of the highest executive body (the Government or the President). For the most part, but not always, it is a single body (Ministry, service) whose head is appointed according to the general procedure for the appointment of ministers, heads of central executive bodies. In the second case, as is the case in Ukraine, the antitrust authority is not part of the Government (or the Cabinet of the President), not directly accountable to the highest executive body. Emphasis is placed on the procedures for appointing and dismissing the leadership of the antimonopoly body, the relationship of the competitive agency with the highest executive bodies of the state. The law enforcement practice of the competition agency of the European Union - the European Commission in granting permits for 
concentration in strategic areas of the European Union economy where international competition from the People's Republic of China is intensifying is analyzed. The domestic judicial practice of appealing the decree of the President of Ukraine on dismissal of a member of the Antimonopoly Committee of Ukraine is considered. The issue of the role of antitrust authorities and the Government in the field of control over the admissibility of state aid to economic entities is outlined.

Taking into account domestic jurisprudence and US federal law (in particular, the US Federal Trade Commission Law), proposals were made to improve the procedure for dismissal of the First Deputy, Deputy Chairmen of the Antimonopoly Committee of Ukraine, and State Antimonopoly Committee Commissioners of Ukraine.

Key words: antitrust authorities, status of antitrust authorities of foreign countries, Antimonopoly Committee of Ukraine, procedure of dismissal of members of the Antimonopoly Committee of Ukraine, antitrust authorities of the USA. 